Original Research Paper

\title{
Penggunaan Pestisida Nabati Ekstrak Daun Pepaya (Carica Papaya L.) pada Tanaman Kacang Panjang (Vigna Sinensis L.) untuk Mengurangi Dampak Pencemaran Lingkungan di Desa Gunung Selamat, Kec. Bilah Hulu, Kab. Labuhanbatu
}

\author{
Jujuaningsih $^{1}$, Khairul Rizal ${ }^{1}$, Yudi Triyanto ${ }^{1}$, Widya Lestari ${ }^{1}$, Dahrul Aman Harahap ${ }^{1 *}$ \\ ${ }^{\text {I} A g r o t e k n o l o g i, ~ F a k u l t a s ~ S a i n s ~ d a n ~ T e k n o l o g i, ~ U n i v e r s i t a s ~ L a b u h a n b a t u ~}$
}

https://doi.org/10.29303/jpmpi.v3i2.857

Sitasi: Jujuaningsih., Rizal. K., Triyanto, Y., Lestari, W., \& Harahap, D. A. (2021). Penggunaan Pestisida Nabati Ekstrak Daun Pepaya (Carica Papaya L.) pada Tanaman Kacang Panjang (Vigna Sinensis L.) untuk Mengurangi Dampak Pencemaran Lingkungan di Desa Gunung Selamat, Kec. Bilah Hulu, Kab. Labuhanbatu. Jurnal Pengabdian Magister Pendidikan IPA, 4(3)

\author{
Article history \\ Received: 05 Juli 2021 \\ Revised: 19 Juli 2020 \\ Accepted: 30 Juli 2021 \\ *Corresponding Author: \\ Dahrul Aman Harahap, \\ Agroteknologi, Fakultas Sains \\ dan Teknologi, Universitas \\ Labuhanbatu; \\ Email: \\ amandahrul@gmail.com
}

\begin{abstract}
Vegetable pesticides are pesticides whose active ingredients come from plants and other organic materials that control pest attacks on plants, containing many bioactive compounds such as phenolic, alkaloid compounds and also other secondary chemical substances. Papayas are plants originating from Central America. Papaya can grow well in areas that are in tropical climates. Some of the ingredients contained in papaya leaves include papain enzymes, flavonoids, alkaloids, saponins, and tannis. All of the content contained in papaya leaves, the papain enzyme is the most abundant chemical content in papaya leaves because it comes from papaya sap.
\end{abstract}

Keywords: Papain enzyme; Vegetable pesticide; Papaya.

Pestisida kimia yang dipergunakan selain memiliki manfaat untuk menambah hasil produksi pertanian serta penggunaannya yang tidak terkendali akan berakibat pada kesehatan petani itu sendiri dan lingkungan pada umumnya, sehingga akan merugikan. Untuk menanggulangi atau mengurangi dampak negatif dari pestisida tersebut, cara alternatif pengendalian yang dapat dilakukan yaitu dengan menggunakan pestisida alami. Pestisida alami adalah alternatif yang bisa digunakan untuk mengatasi kekurangan pestisida kimia (Nasution, 2019).

Diketahui ada beberapa tumbuhan yang memiliki kandungan zat-zat kimia yang berpotensi untuk pengendalian hama pada tanaman (Dono et al., 2012). Memanfaatkan tumbuhan sebagai bahan aktif pestisida mulai banyak digunakan untuk mengendalikan hama dan penyakit. Wiratno \& Trisawa, (2012) menyatakan bahwa hal ini dikarenakan tumbuhan merupakan sumber bahan kimia potensial yang dapat dimanfaatkan sebagai pestisida yang ramah lingkungan dan sangat aman 
secara kesehatan. Di Indonesia bahan pestisida nabati banyak tersedia di alam.

Salah satu bagian tanaman yang bisa dijadikan pestisida alami yaitu daun pepaya. Daun pepaya (Carica papaya L.) memiliki kandungan senyawa toksik seperti saponin, alkaloid karpain, papain, flavonoid. Pestisida nabati adalah pestisida yang bahan aktifnya berasal dari tanaman atau tumbuhan dan bahan organik lainnya yang berkhasiat mengendailkan serangan hama pada tanaman, mengandung banyak senyawa bioaktif seperti senyawa alkaloid, terpenoid, fenolik, dan juga zat-zat kimia sekunder yang lain. Senyawa bioaktif tersebut bila kita aplikasikan ke tanaman yang terinfeksi Organisme Penggagu Tanaman (OPT), tidak berpengaruh terhadap fotosintesis pertumbuhan ataupun aspek fisiologis tanaman lainnya, namun berpengaruh terhadap sistem saraf otot, keseimbangan hormon, reproduksi, perilaku berupa penarik, anti makan dan sistem pernafasan hama (Setiawati $d k k, 2008$ ). Pestisida daun pepaya diyakini mempunyai efektifitas yang tinggi dan dampak spesifik terhadap organisme pengganggu. Bahan aktif daun pepaya juga tidak berbahaya bagi manusia dan hewan.

Pengabdian ini bertujuan untuk mengetahui penggunaan pestisida alami dalam mengurangi pencemaran lingkungan. Hasil yang diperoleh diharapkan dapat memberi pengetahuan kepada masyarakat, terutama petani-petani yang ada di dusun Siluang I, Desa Gunung Selamat, kecamatan Bilah Hulu, Kabupaten Labuhanbatu provinsi Sumatera Utara tentang pemanfaatan bahan alam untuk pembuatan pestisida serta diperoleh informasi tentang prosedur pembuatan pestisida dari daun pepaya yang efektif.

\section{Metode}

Khalayak sasaran dalam pengebdian ini yaitu tertuju kepada para petani, khususnya di Dusun Siluan I, Desa Gunung Selamat, Kecamatan Bilah Hulu, Kabupaten Labuhanbatu Provinsi Sumatera Utara, dalam penggunaan pestisida nabati/alami.

Bahan-bahan yang digunakan dalam pembuatan pestisida ini adalah daun pepaya (10 lembar), air (2 liter), dan bawang putih (3 siungoptional). Alat-alat yang digunakan dalam pembuatan pestisida, antara lain ember, pisau, saringan, botol sprayer, dan alat tulis.

\section{Cara Kerja Pembuatan Pestisida a. Larutan Pestisida Nabati}

Pembuatan pestisida nabati terlebih dahulu dilakukan dengan pengembilan daun pepaya sebanyak yang dibutuhkan. Duan pepaya dibersihkan, lalu di kering anginkan. Kemudian daun pepaya dihaluskan, bisa dengan cara di cincang atau pun di blender. Hasilnya lalu dicampurkan ke dalam 2 liter air dan 3 siung bawang putih yangjuga sudah di iris-iris. Campur dan aduk-aduk sampai semua tercampur rata. Setelah kiranya sudah tercampur rata, saring air yang sudah tercampur ke dalam ember lain. Setelah itu pindahkan ke botol sprayer, dan siap untuk langsung digunakan.

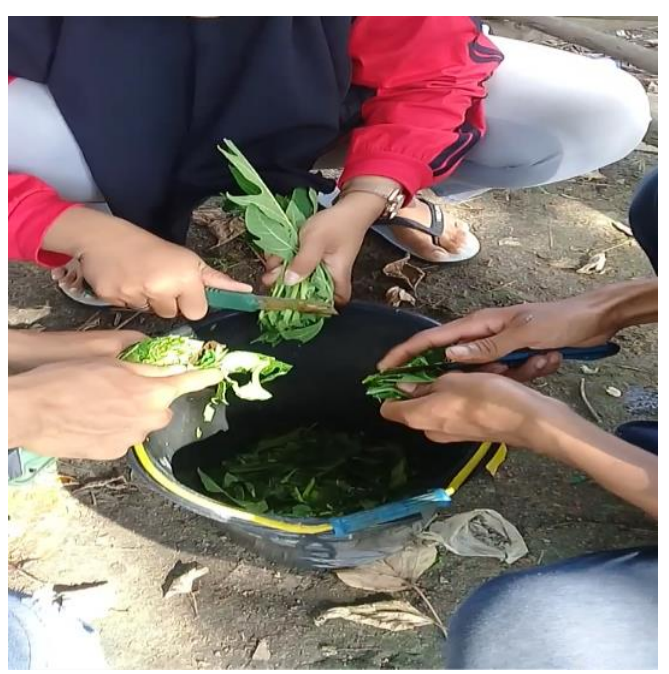

Gambar 1. Pencincangan daun pepaya

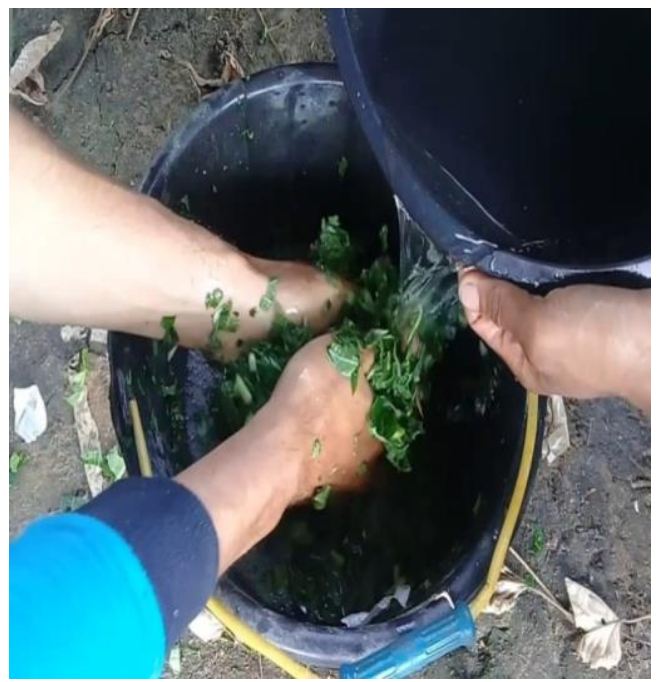

Gambar 2. Pencampuran semua bahan-bahan 


\section{b. Aplikasi Larutan Pestisida Nabati}

Aplikasi larutan pestisida dilakukan dengan cara penyemprotan pada tanaman kacang panjang menggunakan botol sprayer. Penyemprotan ini dilakukan pada pagi ataupun sore hari dengan frekuensi penyemprotan $3 \mathrm{x}$ dalam seminggu. Frekuensi penggunaan pestisida nabati secara permanen tidak menimbulkan kerusakan apapun, seperti halnya dalam penggunaan pestisida kimiawi/sintetis.

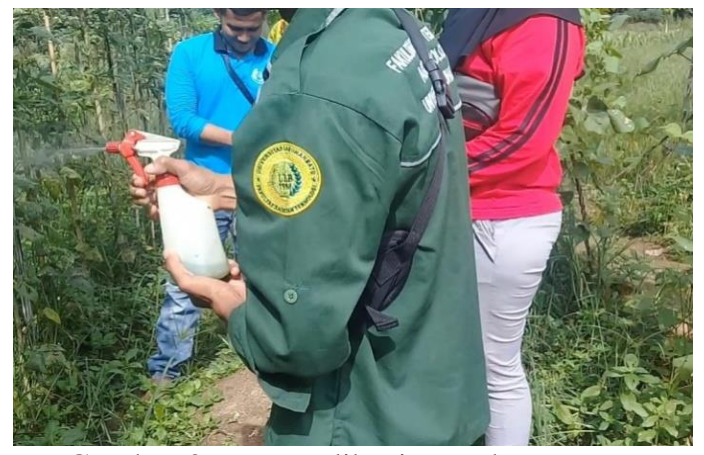

Gambar 3. Pengaplikasian pada tanaman kacang panjang

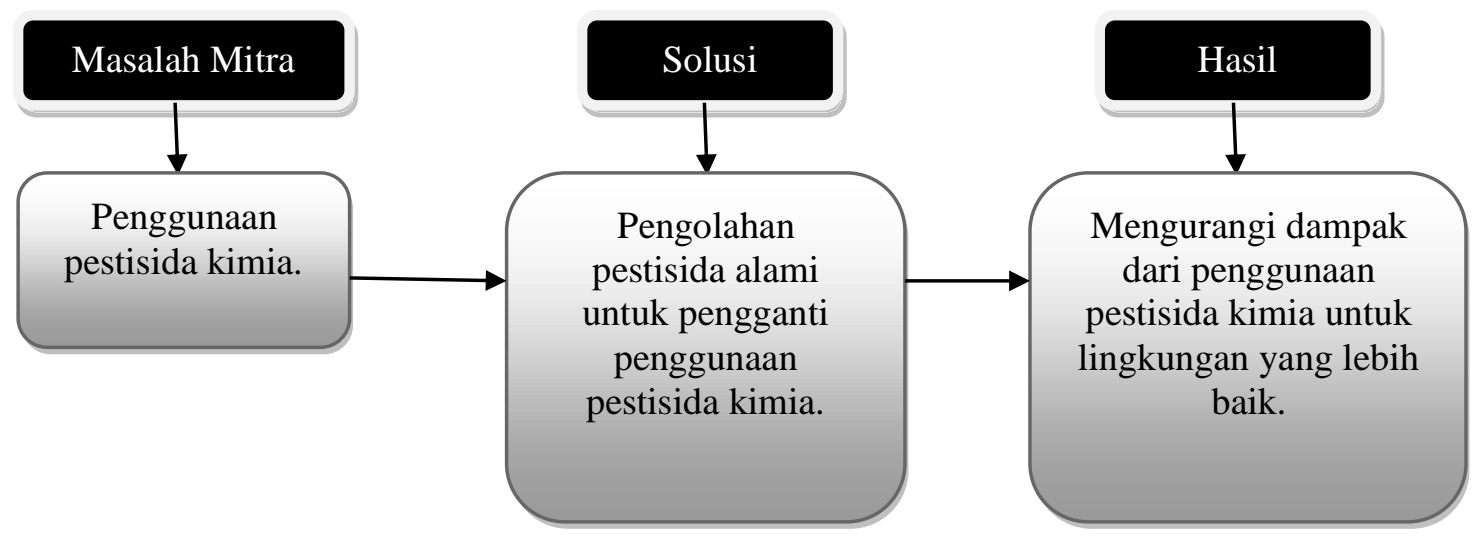

\section{Hasil dan Pembahasan}

Kinerja pestisida nabati dari daun pepaya ini secara menyeluruh dapat mencegah lebih banyak terjadi pencemaran lingkungan akibat pemakaian pestisida kimiawi/sintetis. Selain itu juga mengurangi dampak negatif dari penggunaan pestisida kimiawi/sintetis, yaitu hama akan resisten terhadap sintetis, munculnya residu pestisida, dan kontaminasi ke dalam tubuh manusia/binatang yang mengkonsumsi / memakan pestisida kimia. Penggunaan pestisida nabati ini juga dapat digunakan sebagai pengendalian hama, salah satunya hama penggerek polong yang sering menyerang tanaman polong-polongan (Fabaceae). Jika pengeplikasian nya dilakukan permanen menggantikan pestisida kimiawi/sintetis, maka akan didapatkan hasil yang optimal.

Berdasarkan pengabdian yang dilakukan, menunjukkan bahwa ekstrak daun pepaya yang disemprotkan pada tanaman kacang panjang dapat membantu pengendalian hama penggerek polong, terutama juga dapat meminimalir pencemaran lingkungan. Seperti yang sudah kita ketahui apaapa saja dampak negatif penggunaan pestisida kimiawi/sintetis. Salah satu yang menyebabkan pencemaran lingkungan oleh pestisida kimiawi adalah limbah pestisida nya, yang mana bila pembuangannya tidak benar dapat mencemari lingkungan, juga merupakan potensi bagi orang untuk terpapar secara tidak langsung dengan pestisida. Jika kita secara permanen menggunakan pestisida nabati, tidak akan menimbulkan dampak apapun. Sekalipun dari limbah pestisidanya, karena pestisida nabati yang bahan aktifnya dibuat dari tanaman atau tumbuhan dan bahan organik lainnya.

Sehingga memperkecil kemungkinan manusia atau lingkungan tercemar oleh pestisida ini.

\section{Kesimpulan}

Berdasarkan hasil dan pembahasan dari pengabdian ini, disimpulkan bahwa Ekstrak daun pepaya (penambahan beberapa siung bawang putihoptional) dapat digunakan secara menyeluruh dan juga secara permanen untuk mengurangi dan meminimalir pencemaran lingkungan. Serta dapat digunakan sebagai pengendalian pada hama 
penggerek polong yang menyerang tanaman kacang panjang.

\section{Daftar Pustaka}

Dono, D., Natawigena, W. D., \&Majid, M. G. 2012. Bioactivity of methanolicseed extract of Barringtonia asiatica L. (Kurz)(Lecythidaceae) on biological characters of Spodoptera litura (Fabricius) (Lepidoptera:Noctuidae). Int Res J Agric Sci Soil Sci,2, page 469-475.

Haryanto, E. Suhartini, T. Rahayu, E. 1999. Budidaya kacang panjang. Penebar swadaya. Jakarta.

Marwoto, Suharsono dan Supriyatin. 1999. Hama kedelai dan komponen pengendalian hama terpadu. Monograf BalitKabi (4): 50 hal.

Nasution, M, Taufiqurrahman. 2019. Uji efektivitas beberapa konsentrasi ekstrak daun pepaya terhadap kutu daun Aphis craccivora Koch. (HIMEPTERA:APHIDIDAE) pada tanaman kacang panjang (vigna sinensis $\mathrm{L}$.)

Riyadi, Imron. 2006. Isolasi Protoplas Tanaman Kacang Panjang Secara Enzimati. Buletin plasma nutfah vol.12 no.2. hal 62-68.

Setiawati, W. Dkk. 2008. Tumbuhan bahan pestisida nabati dan cara pembuatannya untuk pengendalian organisme pengganggu tumbuhan (OPT). Balai penelitian tanaman sayuran. Bandung.

Wiratno, S. \& Trisawa, I..M. (2012). Perkembangan Penelitian, Formulasi dan Pemanfaatan Pestisida Nabati. Balai Pengkajian Teknologi Pertanian, Sumatera Selatan. 